Aiste Barbora Uspuriene

doctor of pedagogical sciences, lecturer

Lithuanian Sports University

Kaunas, Lithuania research scientist

Vytautas Magnus University

Kaunas, Lithuania

Deimante Sadzeviciute

student

Lithuanian Sports University

Kaunas, Lithuania

DOI $10.21661 / \mathrm{r}-553524$

\title{
ASPECTS OF COMMUNICATION AND ORGANIZATIONAL COMPETENCES DEVELOPMENT THROUGH SPORT
}

Abstract: sport has a great impact on a person, as it develops mental and physical skills, forms the worldview, patriotism, awareness, creativity of children and adolescents, which can successfully integrate into the modern environment. Research aimto analyze the literature and to reveal aspects of communication and organizational competences development through sport.

Keywords: communication competences, organizational competences, sport.

Уипурене Айсте Барбора д-р пед. наук, преподаватель, лектор Литовский университет спорта

г. Каунас, Литовская Республика научный сотрудник Университет Витаутаса Великого г. Каунас, Литовская Республика 
Садзевичюте Дейманте

студентка

Литовский университет спорта

г. Каунас, Литовская Республика

\section{ОСОБЕННОСТИ РАЗВИТИЯ КОММУНИКАТИВНЫХ И} ОРГАНИЗАЦИОННЫХ КОМПЕТЕНЦИЙ ЧЕРЕЗ СПОРТ

Аннотация: спорт оказывает большое влияние на человека, так как развивает умственные и физические способности, формирует мировоззрение, патриотизм, сознательность, творческие способности детей и подростков, которые могут успешно интегрироваться в современную среду. Цель исследования - проанализировать литературу и выявить особенности развития коммуникативных и организационных компетенций через спорт.

Ключевые слова: коммуникативные компетенции, организационные компетенциии, спорт.

\section{Introduction}

Sport has a great impact on a person, as it develops mental and physical skills, forms the worldview, patriotism, awareness, creativity of children and adolescents, which can successfully integrate into the modern environment. Training in adolescence or youth supports the formation of mental qualities and further development of an individual's psychosocial characteristics (Веселов и Шаров, 2020). Prolonged physical activity reduces the risk of major non-communicable diseases, increases life expectancy and quality, and helps to develop social skills. Professional sports activities promote not only the development of life skills but also higher education (Camiré, Trudel \& Forner, 2009).

Research aim - to analyze the literature and to reveal aspects of communication and organizational competences development through sport.

Results and Conclusions

Communication and organizational skills are common terms for life skill groups that young people can improve them through sport (Jones, Lavallee \& Tod, 2011). 
Organized sports create favorable conditions for positive psychosocial development, which provides an opportunity to develop life skills (Jones \& Lavallee, 2009). Organized sports programs take place in a social setting, so they can provide opportunities to develop skills such as communication, conflict resolution, and empathy. In addition, organized sports experiences can promote citizenship, social success, positive relationships and leadership skills (Logan \& Cuff, 2019).

Communication competence includes various areas of human activity: formulation, coding and transmission of transmitted ideas: acceptance, decoding and perception. In the educational process, it is a core competence for all other key competencies as it is the key to successful communication and collaboration. The importance of the formation and development of communicative competence is largely determined by the period of adolescence, in which complex processes of self-awareness, development of worldview and value system, which determine a new type of relations with society are created (Титов и Невоструева, 2017).

To give young people a positive experience, coaches should develop training and development in life skills, including the acquisition of communication and organizational skills. For example, educators can delegate the responsibility for exercise to athletes, and these must organize the exercises and course of the exercise with the involvement of other athletes (Jones, Lavallee \& Tod, 2011). All tools that are focused on the development of subject-objective components can be used to develop communicative competence, which requires purposeful psychology and pedagogical preparation, which itself must be included in the communicative and personal development block (Petrenko, Gant \& Bondar, 2017). Development of athlete's personality skills is not the easiest process. Therefore, a coach must have a solid knowledge how to develop psychosocial skills properly so that athletes can apply competencies in non-sport-related activities.

Thus, sports activities can not only improve health, but also develop life and social skills. The development of these skills is especially important for a person to be able to self-confidence, communicate freely or increase the circle of friends, as well as to plan, create not only in a sports environment, but also in other areas. Therefore, it is 
very important to create the right conditions that could help to develop communication and organizational skills.

\section{Сиисок литературы}

1. Camiré M. High school athletes' perspectives on support, communication, negotiation and life skill development / M. Camiré, P. Trudel, T. Forneris // Qualitative research in sport and exercise. - 2009.- №1(1). - C. 72-88.

2. Jones M.I. Exploring perceived life skills development and participation in sport / M.I. Jones, D. Lavallee // Qualitative research in sport and exercise. - 2009. №1(1). - C. 36-50.

3. Jones M.I. Developing communication and organization skills: The elite life skills reflective practice intervention / M.I. Jones, D. Lavallee, D. Tod // The sport psychologist. - 2011. - №25(2). - C. 159-176.

4. Logan K. Organized sports for children, preadolescents, and adolescents / K. Logan, S. Cuff // Pediatrics. - 2019. - №143. - C. 1-20. DOI: https://doi.org/10.1542/peds.2019-0997

5. Petrenko I. Communicative competence of sport volunteers / I. Petrenko, H. Gant, A. Bondar // Slobozhanskyi herald of science and sport. - 2017. - №1(57). C. 58-61.

6. Веселов А. А. Влияние спорта на формирование личности / А.А. Веселов, П.В. Шаров // Вестник науки и образования. - 2020. - №13-1(91). - С. 73-75.

7. Титов В.А. Развитие коммуникативной компетентности у подростков / В.А. Титов, И.А. Невоструева // Инновационные технологии в образовании и науке. - 2017 -№8. - С. 176-178. 